\title{
REAKSI PASAR MODAL DI BURSA EFEK INDONESIA TERHADAP PENGUMUMAN PERISTIWA BENCANA BANJIR YANG MELANDA DAERAH KHUSUS IBU KOTA JAKARTA TAHUN 2013
}

\section{CAPITAL MARKET REACTION AT INDONESIAN STOCK EXCHANGE TOWARDS ANNOUNCEMENT FLOOD DISASTER WHICH ATTACKS DAERAH KHUSUS IBUKOTA JAKARTA IN 2013}

\author{
Andri Yuwono \\ Prodi Akuntansi Universitas Negeri Yogyakarta \\ arshavyn23@gmail.com
}

Fakultas Ekonomi Universitas Negeri Yogyakarta

\begin{abstract}
ABSTRAK
Tujuan Penelitian ini adalah untuk menguji apakah peristiwa bencana banjir yang melanda DKI Jakarta tahun 2013 mampu mempengaruhi kegiatan di pasar modal Indonesia. Metode pengumpulan data yang digunakan dalam penelitian ini adalah metode dokumentasi yaitu data yang dikumpulkan dan diolah oleh pihak lain yang berasal dari publikasi Bursa Efek Indonesia. Sampel yang digunakan dalam penelitian ini adalah saham yang termasuk kedalam sektor consumer goods industy dan sub sektor retail. Analisis yang digunakan adalah event study dan uji beda. Abnormal return dihitung berdasarkan expected return yang diperoleh dengan menggunakan Single Index Market Model (SIMM). Periode pengamatan selama 65 hari bursa yang terdiri dari dua periode yaitu 44 hari periode estimasi dan 21 hari periode peristiwa yang terdiri 1 hari peristiwa, 10 hari sebelum peristiwa dan 10 hari setelah peristiwa dijadikan periode jendela untuk mengukur reaksi. Hasil penelitian ini menunjukkan bahwa terdapat abnormal return positif pada saham yang bergerak di sektor consumer goods industry dan sub sektor retail di hari peristiwa. Abnormal return positif juga terjadi pada saat hari pertama, kedua, keempat, kelima, kedelapan dan kesepuluh. Uji perbedaan menunjukkan bahwa secara statistik terdapat perbedaan rata-rata abnormal return pada saham yang bergerak di sektor consumer goods industry dan sub sektor retail sebelum dan setelah peristiwa. Sedangkan untuk rata-rata aktivitas volume perdagangan saham tidak terdapat perbedaan yang signifikan secara statistik.
\end{abstract}

Kata kunci: Studi Peristiwa, Abnormal Return, dan Volume Perdagangan Saham.

\section{ABSTRACT}

The objective of this research is to test of whether the flood disaster which attacks DKI Jakarta in 2013 is able to affect the activities at Indonesian capital market. The collecting data method used in this research is a documentation method that is the data which is collected and processed by other party which comes from the 
publication of Indonesia Stock Exchange. The sample used in this research is the stock that belongs to the sector of consumer goods industy and the retail subsector. The analysis used in this research are event study and diversification test. Abnormal Return is calculated based on expected return which is gained by using Single Index Market Model (SIMM). Observation period is up to 65 days of stock exchange which consists of two periods which are 44 days as estimation period and 21 days as incident period that consists of 1 day as incident day, 10 days before the incident and 10 days after the incident used as window period to survey the reactions. The result of this research shows that there is positive abnormal return on the stock that afoot on the sector of consumer goods industry and on the retail sub-sector in the incident day. Positive Abnormal return also happens upon the first day, second day, fourth day, fifth day, eighth day and on the tenth day. Diversification Test shows that statistically exists a difference on the average of abnormal return on the stock that afoot on the sector of consumer goods industry and on the retail sub-sector before and after the flood disaster. Meanwhile, for the volume activity average of stock exchange, there is statistically no significant differences.

Keyword: Event Study, Abnormal Return, and Trading Volume Activity.

\section{A. PENDAHULUAN}

Pada masa sekarang ini pasar modal semakin banyak mendapat perhatian, baik dari kalangan investor, emiten maupun pemerintah, karena perannya yang sangat mendukung perekonomian. Dalam perkembangannya, fluktuasi harga saham di pasar modal dapat dipengaruhi beberapa faktor ekonomi dan non ekonomi (Inda Kristiana dan Sri Suratna, 2005:122). Walaupun tidak terkait secara langsung dengan dinamika yang terjadi di pasar modal, namun pengaruh lingkungan non ekonomi tidak dapat dipisahkan dari aktivitas pasar modal. Isuisu mengenai kepedulian terhadap lingkungan hidup, hak asasi manusia, peristiwa-peristiwa politik dan kenegaraan serta kerusuhan-kerusuhan yang menyebabkan ketidakpastian politik dan keamanan, sering menjadi faktor utama pemicu fluktuasi harga saham di bursa efek secara seluruh dunia (Marwan Asri dan Faizal Arief, 1998:137).

Bursa saham di suatu negara umumnya sensitif terhadap berbagai peristiwa disekitarnya. Sangat menarik untuk melakukan penelitian mengenai reaksi pasar modal terhadap peristiwa yang diakibatkan oleh faktor non ekonomi yang terjadi di Indonesia. Memasuki awal tahun 2013, DKI Jakarta sudah dilanda bencana banjir yang sudah dirasakan sejak tanggal 15-16 Januari 


\section{JURNAL NOMINAL / VOLUME II NOMOR II / TAHUN 2013}

2013 terutama untuk daerah-daerah yang dekat dengan bantaran sungai Ciliwung. Apabila dilihat dari segi dampaknya, bencana banjir dapat dikelompokkan ke dalam peristiwa yang mempunyai dampak pada seluruh perusahaan di suatu industri (Jogiyanto 2010b:43). Banjir di Jakarta tidak hanya mengganggu aktivitas ekonomi ibu kota tetapi juga aktivitas ekonomi secara nasional. Hal ini mengakibatkan risiko kerugian yang tinggi yang diakibatkan oleh faktor non ekonomi, sehingga adanya peristiwa bencana alam dengan skala tingkat nasional khususnya bencana banjir yang melanda DKI Jakarta, cenderung mendapat respon negatif dari pelaku pasar.

Terdapat sejumlah analisis pasar modal yang disampaikan dalam media massa berkaitan dengan prediksi dan kondisi pasar di sekitar pengumuman peristiwa banjir yang melanda DKI Jakarta. Analisis ini berkaitan dengan ekspektasi semua pihak terhadap banjir yang melanda DKI Jakarta yang akan mempengaruhi kegiatan perekonomian secara nasional. Analisis yang ada memberikan masukan bagi para pelaku pasar terhadap kemungkinan reaksi pasar modal berkaitan dengan peristiwa banjir yang melanda DKI Jakarta. Dengan menciptakan sebuah skenario yang tepat dan melihat kondisi pasar di sekitar peristiwa, para pelaku pasar melakukan sejumlah spekulasi terhadap saham-saham terpilih untuk meningkatkan keuntungan pada saat yang tepat.

Dalam pengumuman peristiwa banjir yang melanda DKI Jakarta, para pelaku pasar modal secara otomatis akan melakukan sejumlah transaksi yang mereka anggap dapat memberikan keuntungan maksimal, hal ini yang merupakan motif rasional bagi setiap investor sebagai pelaku pasar. Dengan asumsi tersebut, kemudian terjadi pertemuan permintaan dan penawaran terhadap saham tertentu, baik dari sisi harga maupun volume perdagangan saham. Hal ini menggambarkan keputusan setiap individu pelaku pasar yang pada akhirnya secara agregrat atau keseluruhan mencapai konsesus dalam harga dan volume perdagangan saham.

Kriteria utama pemilihan peristiwa untuk diteliti adalah pengumuman peristiwa bencana banjir yang melanda DKI Jakarta berskala nasional dan banyak mendapatkan sorotan luas di media massa baik nasional maupun asing. Joko Tri Haryanto (Bisnis Indonesia, 18 Januari 2013) menyatakan bahwa 
banjir yang melanda DKI Jakarta, semakin menjadikan kota Jakarta tidak popular di dunia internasional.

Penelitian ini bertujuan untuk menguji ada tidaknya reaksi pasar terhadap pengumuman peristiwa banjir yang melanda DKI Jakarta tanggal 17 Januari 2013 dengan menggunakan studi peristiwa (event study). Reaksi pasar ditunjukkan dengan adanya perubahan harga dari sekuritas bersangkutan. Selain menguji reaksi pasar, tujuan lain yang ingin dicapai dari penelitian ini adalah untuk mengetahui pengaruh terhadap volume perdagangan pada kurun waktu terjadinya peristiwa tersebut untuk memperoleh gambaran yang lebih komprehensif tentang reaksi pasar.

\section{B. METODE PENELITIAN}

\section{Jenis Penelitian}

Penelitian ini menggunakan metode penelitian event study yang berfokus pada pengujian reaksi pasar terhadap suatu peristiwa (event) yang informasinya dipublikasikan sebagai suatu pengumuman. Event study dapat digunakan untuk menguji kandungan informasi (information content) dari suatu pengumuman dan dapat juga digunakan untuk menguji efisiensi pasar bentuk setengah kuat (Jogiyanto, 2010a:555).

\section{Waktu dan Tempat Penelitian}

Penelitian ini dilakukan dengan mengambil data dari Fact Book, IDX Montly Statistics, dan terbitan eksternal lain (Koran Kompas, Bisnis Indonesia, atau website). Pengambilan data untuk penelitian dilakukan pada bulan Februari 2013

\section{Sampel}

Setelah dilakukan pengambilan sampel dengan menggunakan teknik purposive sampling maka jumlah emiten yang dijadikan sampel akhir dalam penelitian ini berjumlah 36 emiten

Teknik yang digunakan dalam pengambilan sampel dilakukan dengan kriteria (1) Saham tercatat sebagai emiten di BEI yang termasuk dalam kelompok perusahaan sektor consumer goods industry dan Sub Sektor Retail. (2) Saham tercatat sebagai emiten di Bursa Efek Indonesia dan tidak 
pernah mengalami de-listing selama periode penelitian dari tanggal 22 Oktober 2012 sampai tanggal 1 Februari 2013. (3) Aktif diperdagangkan selama periode penelitian yaitu 22 Oktober 2012 sampai tanggal 1 Februari 2013. (4) Saat periode peristiwa (event period) perusahaan-perusahaan yang sahamnya masuk dalam kategori sektor consumer goods industry dan sub sektor retail tersebut tidak melakukan stock split, pengumuman dividen, merger, righ issue, maupun corporate action lainnya selama periode pengamatan. Hal ini bertujuan untuk menghindari adanya efek pengganggu (confounding effect) akibat pengumuman tersebut.

Periode waktu penelitian ini terdiri dari 44 hari periode estimasi (23 Oktober 2012 - 02 Januari 2013), 10 hari periode jendela sebelum tanggal peristiwa (03 Januari 2013 - 16 Januari 2013), dan 10 hari periode jendela setelah tanggal peristiwa (18 Januari 2013 - 1 Februari 2013). Hari pengumuman peristiwa jatuh pada hari Kamis tanggal 17 Januari 2013. Periode waktu tersebut dipilih sebab dalam rentang waktu tersebut merupakan waktu-waktu yang rawan dari pelaku pasar saham untuk mengambil ancang-ancang berspekulasi dalam melakukan transaksi jual beli saham.

\section{Definisi Operasional Variabel}

\section{a. Abnormal Return}

Tingkat keuntungan saham akan diukur dengan abnormal return (tingkat keuntungan tidak normal). Abnormal Return disebut excess return merupakan kelebihan dari return yang sesungguhnya terjadi terhadap return normal atau return ekspektasi.

\section{b. Volume Perdagangan Saham}

volume perdagangan saham diukur dengan melihat indikator aktivitas volume perdagangan, selanjutnya disebut Trading Volume Activity (TVA). Trading Volume Activity merupakan alat untuk mengamati reaksi pasar modal melalui pergerakan volume perdagangan pada saat pasar modal tersebut diteliti. 


\section{JURNAL NOMINAL / VOLUME II NOMOR II / TAHUN 2013}

\section{Teknik Pengumpulan Data dan Pengujian Hipotesis}

\section{a. Data}

Data yang dikumpulkan untuk digunakan dalam penelitian ini meliputi.

1. Tanggal pengumuman peristiwa banjir yang melanda DKI Jakarta, yang digunakan sebagai hari terjadinya pengumuman peristiwa $\left(t_{0}\right)$.

2. Nama saham atau nama perusahaan yang dijadikan sampel adalah yang masuk dalam sektor consumer goods industry dan sub sektor retail selama periode pengamatan.

3. Harga pasar saham harian selama periode pengamatan.

4. Volume perdagangan saham harian selama periode pengamatan.

5. Indeks Harga Saham Gabungan di selama periode pengamatan.

6. Total jumlah saham beredar emiten yang diteliti.

\section{b. Pengujian Hipotesis}

Penelitian ini menggunakan metode analisis event study yang banyak dipakai dalam penelitian-penelitian event study, antara lain Pamela Peterson (1989), Mark P. Kritzman (1994), Marwan Asri (1996), Felicia Marston (1996), Craig MacKinlay (1997), dan Ana Paula Serra (2002).

\section{1) Pengujian Hipotesis 1}

Menghitung abnormal return

Abnormal return (AR) saham selama kejadian didefinisikan sebagai selisih antara return sesungguhnya dengan return ekspektasian. Return dari saham i pada hari ke-t adalah (Jogiyanto, 2010):

$$
\mathrm{AR}_{\text {it }}=\mathrm{R}_{\mathrm{it}}-\mathrm{E}\left(\mathrm{R}_{\mathrm{it}}\right)
$$

$\mathrm{AR}_{\mathrm{it}}=$ abnormal return saham i pada hari ke-t.

$\mathrm{R}_{\mathrm{it}} \quad=$ return sesungguhnya untuk saham i pada hari ke-t.

$\mathrm{E}\left(\mathrm{R}_{\mathrm{it}}\right)=$ expected return untuk saham i pada hari ke-t.

Dalam penelitian ini, Return ekspektasian atau $\mathrm{E}\left(\mathrm{R}_{\mathrm{it}}\right)$ dihitung dengan menggunakan Single Index Market Model (SIMM). Dengan menggunakan model ini maka diperlukan model estimasi, dengan rumus berikut ini.

$$
\mathrm{E}\left(\mathrm{R}_{\mathrm{it}}\right)=\alpha_{\mathrm{i}}+\beta_{\mathrm{i}} \cdot \mathrm{E}\left(\mathrm{R}_{\mathrm{Mt}}\right)
$$

$\mathrm{E}\left(\mathrm{R}_{\mathrm{it}}\right)=$ return ekspektasian saham i pada hari ke-t. 


\section{JURNAL NOMINAL / VOLUME II NOMOR II / TAHUN 2013}

$\alpha_{\mathrm{i}} \quad=$ rata-rata kelebihan pengembalian saham pada suatu periode yang akan terealisasi pada tingkat pengembalian pasar nol.

$\beta_{\mathrm{i}} \quad=$ sensitivitas suatu saham.

$\mathrm{E}\left(\mathrm{R}_{\mathrm{Mt}}\right)=$ return saham pada hari ke-t.

Koefisien $\alpha$ dan $\beta$ diperoleh dari perhitungan persamaan regresi dari time series dari return saham harian $\left(\mathrm{R}_{\mathrm{it}}\right)$ dengan return saham pasar $\left(\mathrm{R}_{\mathrm{Mt}}\right)$. Dari koefisien $\alpha$ dan $\beta$ tersebut dapat dihitung return ekspektasi tiap-tiap saham $E\left(R_{i t}\right)$.

cumulative abnormal return (CAR) harian tiap-tiap saham selama periode event dengan rumus (Jogiyanto, 2010).

$$
\mathrm{CAR}=\sum_{\mathrm{t}=-10}^{\mathrm{t}=+10}\left(\mathrm{AR}_{\mathrm{it}}\right)
$$

$\mathrm{CAR}=$ cumulative abnormal return.

$\sum \mathrm{AR}_{\text {it }}=$ total abnormal return saham i pada waktu hari ke-t.

cumulative average abnormal return (CAAR) portofolio dengan rumus (Jogiyanto, 2010):

$$
\mathrm{CAAR}_{\mathrm{t}}=\sum_{\mathrm{t}=-10}^{\mathrm{t}=+10} \mathrm{AAR}_{\mathrm{t}}
$$

$\mathrm{CAAR}_{\mathrm{t}}=$ cumulative average abnormal return pada hati ke-t.

$\sum \mathrm{AAR}_{\mathrm{t}}=$ total rata-rata return tidak normal saham i pada waktu $\mathrm{t}$.

Melakukan analisis uji signifikasi terhadap nilai return tidak normal dengan uji t, dengan rumus sebagai berikut (Jogiyanto, 2010):

$$
\mathrm{t}-\text { hitung }=\frac{\sum_{\mathrm{i}=1}^{\mathrm{N}} \mathrm{SAR}_{\mathrm{it}}}{\sqrt{\mathrm{N}}}
$$

$\mathrm{t}-$ hitung $=\mathrm{t}$ hitung untuk masing-masing hari ke $\mathrm{t}$ di periode peristiwa .

$\mathrm{SAR}_{\mathrm{it}}=$ standarized abnormal return saham $\mathrm{i}$ hari ke-t di periode peristiwa.

$\mathrm{N}=$ jumlah sekuritas.

kesalahan standar estimasi yang dihitung dengan rumus (Jogiyanto, 2010)

$$
\sigma_{\mathrm{i}}=\sqrt{\frac{\sum_{\mathrm{j}=3}^{\mathrm{t}}\left(\mathrm{R}_{\mathrm{ij}}-\mathrm{E}\left(\mathrm{R}_{\mathrm{i}}\right)\right)^{2}}{\mathrm{~T}_{1}-2}}
$$




\section{JURNAL NOMINAL / VOLUME II NOMOR II / TAHUN 2013}

$\sigma_{\mathrm{i}} \quad=$ standard deviation estimasi untuk saham $\mathrm{i}$.

$\mathrm{R}_{\mathrm{ij}} \quad=$ actual return saham $\mathrm{i}$ untuk hari ke $\mathrm{j}$ selama periode estimasi.

$\mathrm{E}\left(\mathrm{R}_{\mathrm{i}}\right) \quad=$ expected return saham $\mathrm{i}$ selama periode estimasi.

$\mathrm{T}_{1} \quad=$ jumlah hari di periode estimasi, yaitu dari tanggal ke-t3 sampai dengan tanggal ke-t4 yaitu sebesar $\mathrm{T}_{1}=\mathrm{t}_{4}-\mathrm{t}_{3}$

standard deviation of forecast saham i pada hari ke $\mathrm{t}$ di periode peristiwa dihitung sebagai berikut:

$$
\mathrm{SDF}_{i t}=\sqrt[\sigma_{\mathrm{i}}]{1+\frac{1}{\mathrm{~T}_{1}}+\frac{\left(\mathrm{R}_{\mathrm{Mt}}-\overline{\mathrm{R}}_{\mathrm{M}}\right)^{2}}{\sum_{\mathrm{j}=\mathrm{t} 3}^{\mathrm{t}}\left(\mathrm{R}_{\mathrm{Mt}}-\overline{\mathrm{R}}_{\mathrm{M}}\right)^{2}}}
$$

$\mathrm{SDF}_{\mathrm{it}}=$ standard deviation of forecast saham $\mathrm{i}$ pada hari ke $\mathrm{t}$ di periode peristiwa.

$\sigma_{\mathrm{i}} \quad=$ kesalahan standar estimasi untuk sekuritas ke-i.

$\mathrm{R}_{\mathrm{Mt}} \quad=$ return indeks pasar tanggal ke-t di periode peristiwa.

$\mathrm{R}_{\mathrm{Mj}} \quad=$ return indeks pasar tanggal ke-j di periode estimasi.

$\overline{\mathrm{R}_{\mathrm{M}}} \quad=$ rata-rata return indeks pasar selama periode estimasi.

$\mathrm{T}_{1}=$ jumlah hari diperiode estimasi, dari hari ke-t3 sampai dengan hari ke-t4.

standardized abnormal return untuk masing-masing saham dengan rumus (Jogiyanto, 2010):

$$
\mathrm{SAR}_{\mathrm{it}}=\frac{\mathrm{AR}_{\mathrm{it}}}{\mathrm{SDF}_{\mathrm{it}}}
$$

$\mathrm{SAR}_{\mathrm{it}}=$ standardized abnormal return saham $\mathrm{i}$ hari ke $\mathrm{t}$ di periode peristiwa.

$\mathrm{AR}_{\mathrm{it}}=$ abnormal return saham ke-i pada hari ke-t di periode peristiwa.

$\mathrm{SDF}_{\mathrm{it}}=$ standard deviation of forecast saham $\mathrm{i}$ pada hari ke $\mathrm{t}$ di periode peristiwa.

\section{2) Pengujian Hipotesis 2}

Menghitung rata-rata abnormal return seluruh saham yang dijadikan sampel sebelum dan sesudah peristiwa, dengan rumus (Marwan Asri dan Faizal Arief, 1998):

$$
\overline{A R}_{\text {before }}=\frac{\sum_{t=-10}^{t=-1}\left(A R_{\text {before }}\right)}{n}
$$

Dan 


$$
\overline{A R}_{\text {after }}=\frac{\sum_{t=+10}^{t=+1}(\text { AR } a f t e r)}{n}
$$

$\overline{A R}_{\text {before }}=\quad$ rata-rata abnormal return sebelum peristiwa.

$\overline{A R}_{\text {after }}=\quad$ rata-rata abnormal return setelah peristiwa.

$A R_{\text {before }}=$ abnormal return sebelum peristiwa.

$A R_{\text {after }}=$ abnormal return setelah peristiwa.

$\mathrm{n}=$ jumlah saham yang diamati.

Menghitung deviasi standar rata-rata abnormal return sebelum dan setelah peristiwa, dengan rumus (Marwan Asri dan Faizal Arief, 1998):

$\sigma_{\text {before }}=\frac{\sqrt{\sum_{\mathrm{t}=-10}^{\mathrm{t}=-1}\left(\mathrm{AR}_{\text {before }}-\mathrm{AAR}_{\text {before }}\right)^{2}}}{(\mathrm{n}-1)}$

Dan

$\sigma_{\mathrm{after}}=\frac{\sqrt{\sum_{\mathrm{t}=+10}^{\mathrm{t}=+1}\left(\mathrm{AR}_{\mathrm{after}}-\mathrm{AAR}_{\mathrm{after}}\right)^{2}}}{(\mathrm{n}-1)}$

$\sigma_{\text {before }}=\quad$ standar deviasi abnormal return sebelum peristiwa.

$\sigma_{\text {after }}=$ standar deviasi abnormal return setelah peristiwa.

$\mathrm{n} \quad=\quad$ jumlah saham yang diamati.

Melakukan uji statistik-t pada tingkat signifikasi $(\alpha)$ sebesar 5\%. Dihitung dengan menggunakan rumus berikut ini (Marwan Asri dan Faizal Arief, 1998):

$\mathrm{t}=\frac{\overline{\mathrm{AR}}_{\text {after }}-\overline{\mathrm{AR}}_{\text {before }}}{\frac{\sigma \mathrm{after}^{2}}{\mathrm{n}}+\frac{\sigma \text { before }^{2}}{\mathrm{n}}}$

$\overline{\mathrm{AR}}_{\text {before }}=\quad$ rata-rata abnormal return sebelum peristiwa.

$\overline{\mathrm{AR}}_{\mathrm{after}}=\quad$ rata-rata abnormal return setelah peristiwa.

$\sigma_{\text {before }}=\quad$ standar deviasi abnormal return sebelum peristiwa.

$\sigma_{\mathrm{after}}=$ standar deviasi abnormal return setelah peristiwa.

$\mathrm{n}=$ total saham yang dijadikan sampel.

\section{3) Pengujian Hipotesis 3}

Menguji aktivitas volume perdagangan saham i pada periode $\mathrm{t}$ dengan rumus (Marwan Asri dan Faizal Arief, 1998):

$\mathrm{TVA}_{\mathrm{it}}=\frac{\sum \text { saham i yang diperdagangkan pada hari } \mathrm{t}}{\sum \text { jumlah i yang beredar pada hari } \mathrm{t}}$ 
Menghitung rata-rata volume perdagangan seluruh saham yang dijadikan sampel sepuluh hari sebelum dan sepuluh hari setelah peristiwa, dengan rumus (Marwan Asri dan Faizal Arief, 1998):

$\overline{\mathrm{TVA}}_{\text {before }}=\frac{\sum_{\mathrm{t}=-10}^{\mathrm{t}=-1} \mathrm{TVA}_{\text {before }}}{10}$

Dan

$\overline{\mathrm{TVA}}_{\mathrm{after}}=\frac{\sum_{\mathrm{t}=+1}^{\mathrm{t}=+10} \mathrm{TVA}_{\mathrm{after}}}{10}$

Menghitung standar deviasi rata-rata volume perdagangan saham sebelum dan setelah peristiwa, dengan menggunakan rumus (Marwan Asri dan Faizal Arief, 1998):

$\sigma_{\text {before }}=\frac{\sqrt{\sum_{\mathrm{t}=-10}^{\mathrm{t}=-1}\left(\mathrm{TVA}-\mathrm{TVA}_{\mathrm{before}}\right)^{2}}}{(\mathrm{n}-1)}$

Dan

$\sigma_{\mathrm{after}}=\frac{\sqrt{\sum_{\mathrm{t}=+1}^{\mathrm{t}=+10}\left(\mathrm{TVA}-\mathrm{TVA}_{\mathrm{after}}\right)^{2}}}{(\mathrm{n}-1)}$

$\sigma_{\text {before }}=$ standar deviasi abnormal return sebelum peristiwa.

$\sigma_{\text {after }}=$ standar deviasi abnormal return setelah peristiwa.

$\mathrm{n}=$ periode waktu

Melakukan uji statistik (uji-t) untuk mengetahui signifikasi TVA sebelum dan seudah peristiwa, pada tingkat signifikasi $(\alpha)$ sebesar 5\%. Dihitung dengan menggunakan rumus berikut ini (Marwan Asri dan Faizal Arief, 1998):

$$
\mathrm{t}=\frac{\overline{\mathrm{TVA}}_{\text {after }}-\overline{\mathrm{TVA}}_{\text {before }}}{\frac{\sigma \text { after }^{2}}{\mathrm{n}}+\frac{\sigma \text { before }^{2}}{\mathrm{n}}}
$$

$\mathrm{TVA}_{\text {before }} \quad=$ rata-rata abnormal return sebelum peristiwa.

TVA $_{\text {after }}=$ rata-rata abnormal return setelah peristiwa.

$\sigma_{\text {before }}=$ standar deviasi abnormal return sebelum peristiwa.

$\sigma_{\text {after }}=$ standar deviasi abnormal return setelah peristiwa.

$\mathrm{n} \quad=\quad$ periode waktu. 


\section{JURNAL NOMINAL / VOLUME II NOMOR II / TAHUN 2013}

\section{HASIL PENELITIAN DAN PEMBAHASAN}

Pengujian statistik terhadap nilai abnormal return bertujuan untuk melihat signifikasi abnormal return yang terjadi selama event windows. Pengujian abnormal return ini dilakukan dengan mencari selisih antara hasil yang diperoleh dengan hasil yang diharapkan investor. Abnormal return yang diperoleh investor memiliki dua arah, yaitu positif dan negatif.

Untuk melihat ada atau tidaknya abnormal return saham pada sebelum dan setelah pengumuman peristiwa bencana banjir yang melanda DKI Jakarta tahun 2013, akan dicari dengan menggunakan rumus One Sample T Test.

Tabel 1. Hasil Analisis One-Sample T Test Abnormal Return

\begin{tabular}{|l|l|l|l|}
\hline \multicolumn{4}{|c|}{ Test Value $=0$} \\
\hline Waktu & \multicolumn{1}{|c|}{$\mathrm{t}$} & $\begin{array}{c}\text { Sig. } \\
\text { (2-tailed) }\end{array}$ & $\begin{array}{c}\text { Mean } \\
\text { Difference }\end{array}$ \\
\hline $\mathrm{t}-10$ & $-1,555$ & 0,129 & $-0,0147854$ \\
\hline $\mathrm{t}-9$ & 1,008 & 0,320 & 0,0067067 \\
\hline $\mathrm{t}-8$ & $-1,991$ & 0,054 & $-0,0153445$ \\
\hline $\mathrm{t}-7$ & $-0,977$ & 0,335 & $-0,0034704$ \\
\hline $\mathrm{t}-6$ & $-1,186$ & 0,244 & $-0,0052956$ \\
\hline $\mathrm{t}-5^{*}$ & $-2,328$ & 0,026 & $-0,0111865$ \\
\hline $\mathrm{t}-4$ & 0,440 & 0,662 & 0,0023919 \\
\hline $\mathrm{t}-3^{*}$ & 2,827 & 0,008 & 0,0102676 \\
\hline $\mathrm{t}-2$ & $-1,737$ & 0,091 & $-0,0089289$ \\
\hline $\mathrm{t}-1$ & 0,350 & 0,729 & 0,0014293 \\
\hline $\mathrm{t}-0^{*}$ & 3,823 & 0,001 & 0,0138868 \\
\hline $\mathrm{t}+1$ & 0,653 & 0,518 & 0,0034143 \\
\hline $\mathrm{t}+2$ & 1,571 & 0,125 & 0,0079188 \\
\hline $\mathrm{t}+3$ & $-0,366$ & 0,717 & $-0,0008399$ \\
\hline $\mathrm{t}+4^{*}$ & 2,341 & 0,025 & 0,0146871 \\
\hline $\mathrm{t}+5$ & 0,348 & 0,730 & 0,0021130 \\
\hline $\mathrm{t}+6^{*}$ & $-4,384$ & 0,000 & $-0,0184049$ \\
\hline $\mathrm{t}+7$ & $-1,284$ & 0,208 & $-0,0064401$ \\
\hline $\mathrm{t}+8^{*}$ & 2,495 & 0,017 & 0,0099139 \\
\hline $\mathrm{t}+9^{*}$ & $-2,060$ & 0,047 & $-0,0078881$ \\
\hline $\mathrm{t}+10^{*}$ & 2,080 & 0,045 & 0,0104419 \\
\hline
\end{tabular}

*) signifikan

Sumber: Data yang diolah.

Analisis SPSS dengan menggunakan One-Sample T Test terhadap nilai abnormal return saham pada peristiwa bencana banjir yang melanda DKI Jakarta tahun 2013 yang terjadi selama periode peristiwa, memperlihatkan adanya abnormal return signifikan yang diterima oleh investor, yaitu pada t-5 
$(2,6 \%), \mathrm{t}-3(0,8 \%), \mathrm{t} 0(0,1 \%), \mathrm{t}+4(2,5 \%), \mathrm{t}+6(0 \%), \mathrm{t}+8(1,7 \%), \mathrm{t}+9(4,7 \%)$ dan t+10 (4,5\%). Hal ini menunjukkan adanya reaksi yang diberikan pasar modal terhadap pengumuman peristiwa bencana banjir yang melanda DKI Jakarta tahun 2013.

Pengujian terhadap perbedaan reaksi yang diberikan pasar modal melalui rata-rata abnormal return antara sebelum dan setelah pengumuman peristiwa bencana banjir yang melanda DKI Jakarta tahun 2013 dilakukan dengan mencari Average Abnormal Return (AAR) dari seluruh sampel saham selama 10 hari sebelum dan 10 hari setelah peristiwa. Nilai rata-rata abnormal return antara sebelum dan setelah pengumuman peristiwa bencana banjir yang melanda DKI Jakarta tahun 2013 kemudian dianalisis menggunakan Paired-Samples T Test terhadap rata-rata abnormal return.

Tabel 2. Uji Beda Abnormal Return Saham

\begin{tabular}{|l|l|l|}
\hline & $\begin{array}{l}\text { Abnormal } \\
\text { return } \\
\text { saham } \\
\text { sebelum } \\
\text { peristiwa }\end{array}$ & $\begin{array}{l}\text { Abnormal } \\
\text { return saham } \\
\text { setelah } \\
\text { peristiwa }\end{array}$ \\
\hline Mean & $-0,003822$ & 0,001492 \\
\hline $\begin{array}{l}\text { Standar } \\
\text { deviasi }\end{array}$ & 0,0127340 & 0,0070939 \\
\hline $\begin{array}{l}\text { t } \\
\text { Sig t }\end{array}$ & $\begin{array}{l}-2,834 \\
0,008\end{array}$ \\
\hline Keterangan & Signifikan \\
\hline
\end{tabular}

Sumber: Data sekunder yang diolah.

Rata-rata abnormal return saham selama 10 hari sebelum pengumuman peristiwa bencana banjir yang melanda DKI Jakarta tahun 2013 (t-10 hingga t-1) diperoleh sebesar $-0,003822$ atau terjadi reaksi negatif dari investor, sedangkan setelah pengumuman peristiwa bencana banjir yang melanda DKI Jakarta $(t+1$ hingga $\mathrm{t}+10$ ) diperoleh rata-rata sebesar 0,001492 atau menunjukkan terjadi kecenderungan reaksi positif. Namun demikian hasil pengujian kemaknaan perbedaan return saham secara statistik diperoleh nilai $\mathrm{t}=-2,834$ dengan signifikansi sebesar 0,008. Nilai sig t diperoleh lebih kecil dari 0,05. Hal ini berarti bahwa pada taraf $5 \%$ terdapat adanya perbedaan yang signifikan pada 
sebelum dan setelah pengumuman peristiwa bencana banjir yang melanda DKI Jakarta tahun 2013.

Pengujian terhadap perbedaan reaksi yang diberikan pasar modal melalui rata-rata aktivitas volume perdagangan saham yang terjadi antara sebelum dan setelah pengumuman peristiwa bencana banjir yang melanda DKI Jakarta tahun 2013 dilakukan dengan mencari Average Trading Volume Activity (ATVA) dari seluruh sampel saham selama 10 hari sebelum dan 10 hari setelah peristiwa. Nilai rata-rata TVA sebelum dan setelah pengumuman peristiwa bencana banjir yang melanda DKI Jakarta tahun 2013 kemudian dianalisis menggunakan Paired-Samples T Test.

Tabel 3. Uji Beda TVA saham

\begin{tabular}{|l|l|l|}
\hline & $\begin{array}{l}\text { TVA } \\
\text { sebelum } \\
\text { peristiwa }\end{array}$ & $\begin{array}{l}\text { TVA setelah } \\
\text { peristiwa }\end{array}$ \\
\hline Mean & 0,001133 & 0,001151 \\
\hline $\begin{array}{l}\text { Standar } \\
\text { deviasi }\end{array}$ & 0,0013806 & 0,0015496 \\
\hline $\begin{array}{l}\mathrm{t} \\
\text { Sig t }\end{array}$ & $\begin{array}{l}-0,093 \\
0,926\end{array}$ \\
\hline Keterangan & Tidak signifikan \\
\hline
\end{tabular}

Sumber: Data sekunder yang diolah.

Rata-rata TVA selama 10 hari sebelum pengumuman peristiwa bencana banjir yang melanda DKI Jakarta tahun 2013 (t-10 hingga t-1) diperoleh sebesar 0,001133 atau terjadi perdagangan saham hingga $0,11 \%$ dari seluruh saham yang ada, sedangkan setelah pengumuman peristiwa bencana banjir yang melanda DKI Jakarta ( $t+1$ hingga $t+10)$ diperoleh rata-rata sebesar 0,001151 atau menunjukkan terjadi perdagangan saham sebesar $0,11 \%$ dari seluruh saham yang ada. Namun demikian hasil pengujian kemaknaan perbedaan TVA secara statistika diperoleh nilai t -0,093 dengan signifikansi sebesar 0,926 nilai sig t diperoleh lebih besar dari 0,05 . Hal ini berarti bahwa pada taraf $5 \%$ tidak terdapat adanya perbedaan TVA yang signifikan antara sebelum dan setelah pengumuman peristiwa bencana banjir yang melanda DKI tahun 2013. 


\section{JURNAL NOMINAL / VOLUME II NOMOR II / TAHUN 2013}

\section{PENUTUP}

\section{Kesimpulan}

Pengumuman peristiwa bencana banjir yang melanda DKI Jakarta tanggal 17 Januari 2013 memberikan abnormal return bagi investor terbukti signifikansi secara statistik. Pada saat kejadian pada tanggal 17 Januari 2013 terjadi rata-rata abnormal return yang positif t-hitung mencapai titik 3,823 yang berarti investor mendapatkan keutungan akibat dari peristiwa yang tidak diantisipasi tersebut. Pada hari kejadian, pertama, dan kedua setelah peristiwa terjadi perubahan arah rata-rata abnormal return menjadi positif, perubahan positif juga terjadi pada hari keempat, kelima, kedelapan dan kesepuluh, terjadi rata-rata abnormal return yang signifikan secara statistik dengan puncak tertinggi di hari kejadian dengan t-hitung sebesar 3,823.

Hasil analisis uji perbedaan rata-rata abnormal return sepuluh hari sebelum dan sepuluh hari setelah peristiwa menunjukkan bahwa secara statistik ada perbedaan yang signifikan antara rata-rata abnormal return sepuluh hari sebelum dengan rata-rata abnormal return sepuluh hari setelah peristiwa

Hasil analisis uji perbedaan rata-rata aktivitas volume perdagangan sepuluh hari sebelum dan sepuluh hari setelah peristiwa menunjukkan bahwa secara statistik tidak ada perbedaan yang signifikan antara rata-rata aktivitas volume perdagangan sepuluh hari sebelum dengan rata-rata aktivitas volume perdagangan sepuluh hari setelah peristiwa.

\section{Saran}

Saran yang dapat diberikan dalam penelitian ini adalah sebagai berikut.

a. Kepada pelaku pasar agar secara terus menerus dilakukan upaya peningkatan kepekaan terhadap peristiwa yang terjadi di luar permasalahan bidang ekonomi yang dimungkinkan dapat berpengaruh terhadap bursa saham.

b. Kepada pemerintah pengambilan keputusan dan kebijakan yang cepat dan tepat serta transparan di segala bidang sehingga memberikan nilai kepercayaan yang tinggi di masyarakat maupun pelaku ekonomi yang memiliki akses terhadap perekonomian global. 


\section{JURNAL NOMINAL / VOLUME II NOMOR II / TAHUN 2013}

\section{E. DAFTAR PUSTAKA}

Eduardus Tandelilin. (2010). Portofolio dan Investasi Teori dan Aplikasi. Edisi ke-1. Yogyakarta:Kanisius.

Homaifar, Ghassem, William L. Randolph, Billy P.Helms dan Mahmoud Haddad. (1988). "American Presidential Elections and Returns of Defence Industry Stocks". Applied Economics. Vol.28. Hal 985-993.

Inda Kristiana dan Sri Suranta. (2005). "Reaksi Pasar Modal Terhadap Peristiwa Pemilu Legislatif dan Peristiwa Pemilu Presiden dan Wakil Presiden Tahun 2004 (Event Study Peristiwa Pemilu 5 April 2004 dan Pemilu 20 September 2004)". Jurnal Akuntansi dan Bisnis. Vol. 5 No. 2. Agustus 2005. Hal 122-136.

Jogiyanto. HM. (2012). Pasar Efisien secara Informasi, Operasional, dan Keputusan. Edisi ke-2. Yogyakarta:BPFE.

(2010a). Teori Portofolio dan Anlisis Investasi. Edisi ke-7. Yogyakarta:BPFE.

(2010b). Studi Peristiwa : Menguji Reaksi Pasar Modal Akibat Suatu Peristiwa. Edisi ke-1. Yogyakarta:BPFE.

Joko Tri Haryanto. (2013). Opini: Ayo Selamatkan Jakarta!. Bisnis Indonesia. 18 Januari 2013. Hal. 2.

Kalra, Rajiv, Glen V. Henderson Jr, dan Gary A. Raines. (1993). "Effects of the Chernobyl Nuclear Accident on Utility Share Prices". Quarterly Journal of Business and Economics. Spring. Vol.32. No.2. Hal 52-77.

Kritzman, Mark P. (1994). "What Practitioners Need To Know About Event Studies". Fiancial Analysts Journal. November-Desember 1994. Hal 1720 .

MacKinlay, A. Craig (1997). "Event Studies in Economics and Finance". Journal of Economic Literature. Vol.XXXV. Maret. Hal 13-39.

Marston, Felicia. (1996). "Differences in Information and Common Stock Returns: Estimation Risk or Unequal Distribution of Information?”. The Financial Review. November . Vol. 31. No. 4. Hal 831-857.

Marwan Asri dan Faizal Arief Setiawan. (1998). "Reaksi Pasar Modal Indonesia Terhadap Peristiwa Politik Dalam Negeri (Event Study pada Peristiwa 27 Juli 1996)". Kelola.No.18/VII/1998. Hal 137-153.

Mohamad Hendratmoko dan Didi Achjari. (2008). "Dampak Pengumuman Penerapan Teknologi Informasi Terhadap Nilai Perusahaan”. Jurnal Riset Akuntansi dan Keuangan. Vol.4 No.1. Februari 2008. Hal 1-21. 
Neni Meidawati dan Mahendra Harimawan. (2004). "Pengaruh Pemilihan Umum Legislatif Indonesia Tahun 2004 Terhadap Return Saham dan Volume Perdagangan Saham LQ-45 di PT Bursa Efek Jakarta". SINERGI Kajian Bisnis dan Manjemen. Vol. 7 No. 1. 2004. Hal 89-101.

Nursiam dan Lastiyono Doso Puteranto. (2004). "Analisis Efisiensi Pasar Modal Indonesia Periode 1998-2000 (Studi pada PT Bursa Efek Jakarta)". Jurnal Akuntansi dan Keuangan. Vol. 3 No.1. April 2004. Hal $1-23$.

Paula Serra, Ana. (2002). "Event Study Tests A Brief Survey". Working Papers da FEP. No.117. Mei. Hal 1-14.

Peterson, Pamela P. (1989). "Event Studies: A Review of Issues and Methodology". Quarterly Journal of Business and Economics. Summer. Vol. 28. Hal 36-66.

Sri Dwi Ari Ambarwati. (2008). "Pengaruh Return Saham dan VolumePerdagangan Saham dan Varian Return Saham Terhadap BidAsk Spread Saham pada Perusahaan Manufaktur yang Tergabung dalam Tergabung dalam Indeks LQ 45 Periode Tahun 2003-2005”. Jurnal Siasat Bisnis. Vol. 12. 1. April 2008. Hal 27-38.

Sugiyono. (2010). Metode Penelitian Bisnis. Alfabeta:Bandung. 